\title{
Identification of a New Waitea circinata Variety Causing Basal Leaf Blight of Seashore Paspalum
}

\author{
S. J. Kammerer, Department of Plant Pathology, University of Florida, Gainesville 32611-0680; L. L. Burpee, Department of Plant \\ Pathology, University of Georgia, Georgia Experiment Station, Griffin 30223; and P. F. Harmon, Department of Plant Pathology, \\ University of Florida, Gainesville
}

\begin{abstract}
Kammerer, S. J., Burpee, L. L., and Harmon, P. F. 2011. Identification of a new Waitea circinata variety causing basal leaf blight of seashore paspalum. Plant Dis. 95:515-522.

Seashore paspalum (Paspalum vaginatum) is a saline-tolerant, warmseason turfgrass species popular for golf course use in tropical and subtropical climates. A new variety of Waitea circinata (proposed as W. circinata var. prodigus) is described as the causal agent of basal leaf blight, a novel disease of seashore paspalum. Foliar necrosis and canopy thinning of seashore paspalum were observed on three different golf course fairways in Florida over an 18-month period. Five isolates with profuse, pink to yellow mycelia and small, salmon-colored or yellow to light-brown sclerotia were cultured from diseased turf foliage. Isolates grew rapidly over a temperature range of 25 to $35^{\circ} \mathrm{C}$ and were initially identified as an uncharacterized variety of $W$. circinata. Internal transcribed spacer sequences of rDNA from the isolates were

compared with sequences from previously described $W$. circinata varieties. The paspalum isolates formed a phylogenetic clade that was distinct from the other $W$. circinata varieties. Pathogenicity was confirmed on 'SeaDwarf' and 'SeaIsle Supreme' seashore paspalum, 'Penncross' creeping bentgrass (Agrostis stolonifera), 'Senesta' bermudagrass (Cynodon dactylon), and 'Dark Horse' roughstalk bluegrass (Poa trivialis). The geographical distribution and potential impact of basal leaf blight is unknown. However, the range of potential turfgrass hosts and environmental conditions conducive for disease development suggest that the pathogen may infect other species in addition to seashore paspalum.
\end{abstract}

Seashore paspalum (SP), Paspalum vaginatum Swartz, is a warm-season grass best adapted to tropical and subtropical climates (25). The species is halophytic (saltwater tolerant) and has been found in South Africa growing along seashores and in brackish waters, but the origin of the grass is uncertain $(8,25)$. Numerous synonyms have been recognized since 1759 , such as $P$. distichum, $P$. foliosum, $P$. reptans, and $P$. reimarioides, to name but a few (9). SP produces a very robust root system with deep, dense rhizomes and stolons (22). Suitable uses range from low-maintenance or remediation turfgrass for saline soils to higher-maintenance plantings such as lawns and golf course turf (9). The plant grows vigorously and is capable of producing a dense, dark-green canopy suitable for amenity turfgrass uses. SP was introduced into the turfgrass market in 1996 as a "next-generation" turf for golf courses that requires less water and fertilizer inputs to maintain a high-quality foliar canopy compared with other warm-season turfgrass species.

SP is susceptible to a range of fungal pathogens and nematodes that affect other warm-season turfgrass species. In greenhouse studies, SP was found to be as susceptible as bermudagrass, Cynodon dactylon (L.) Pers., to the parasitic nematodes Belonolaimus longicaudatus and Hoplolaimus galeatus (15). Samples of SP exhibiting dollar spot symptoms caused by Sclerotinia homoeocarpa F. T. Benn. are routinely received in the University of Florida Extension Plant Disease Clinic (P. Harmon, personal communication). Dollar spot has been reported as a disease of $P$. vaginatum in

Corresponding author: P. F. Harmon, E-mail: pfharmon@ufl.edu

Accepted for publication 22 November 2010.

doi:10.1094/PDIS-03-10-0204

(C) 2011 The American Phytopathological Society
China (19). Take-all root rot, caused by Gaeumannomyces graminis var. graminis (Sacc.) Arx \& D.L. Oliver, an ectotrophic, root-infecting fungus of warm-season turfgrass, also has been diagnosed on SP (11). Large patch, caused by Rhizoctonia solani AG 22 'LP', occurs frequently on SP and may require preventative fungicide applications to prevent turfgrass loss $(2,14,20)$.

In 2007, an unusual disease of SP was observed on three golf courses in Florida. The disease was observed three times during the coldest period of the year for South Florida, in January, but also twice during the hotter periods of the year, in July and September. Symptoms were observed on SP during cold and hot weather, following low and high fertility, and during wet and dry periods. Symptoms included irregular-shaped, blighted patches of turfgrass foliage ranging from 15 to $150 \mathrm{~cm}$ long and 5 to $90 \mathrm{~cm}$ wide. A Rhizoctonia-like fungus, tentatively identified as Waitea circinata, was isolated from necrotic leaves and stolons from samples taken from these locations. W. circinata is recognized as the teleomorph of a number of Rhizoctonia-like fungi $(1,7,18,32,34,36,38)$. Previous work has suggested the use of variety designations for $W$. circinata to further differentiate the species based on biological and molecular genetic differences. Varieties agrostis, circinata, oryzae, and zeae $(7,18,30,34)$ cause distinct diseases on graminaceous hosts but have not been reported on SP. The objective of this study was to assess the biology, pathogenicity, and genetics of isolates of W. circinata sampled from SP in Florida.

\section{Materials and Methods}

Turfgrass sampling and isolate maintenance. Eight golf courses in South Florida with either 'SeaIsle 2000', 'SeaDwarf', or 'SeaIsle Supreme' SP fairways were visited nine times approximately every 2 months from August 2007 to January 2009. One sample, $10.75 \mathrm{~cm}$ in diameter and approximately $15 \mathrm{~cm}$ in depth, was removed from an area exhibiting foliar blight or thinning on each of the eight golf course fairways or roughs at each of the nine 
visits (Fig. 1A and B). Each sample was placed in a polyethylene bag, and the bagged samples were placed on ice. The soil and dead organic matter were washed from each sample. Samples were sliced in half approximately $0.5 \mathrm{~cm}$ below the soil surface, separating the underground stolons, rhizomes, and roots from the aboveground leaves and stolons.

Sixteen aboveground and sixteen belowground necrotic tissue pieces (each approximately 1.5 to $2 \mathrm{~cm}$ in length) were removed from each plug, surface sterilized in $70 \%$ ethanol for $30 \mathrm{~s}$, and rinsed twice for $30 \mathrm{~s}$ with sterilized, deionized water. Samples were blotted dry on sterile tissue and transferred to petri dishes containing either water agar (Bacto agar [Difco Laboratories, Detroit] at $15 \mathrm{~g} /$ liter of deionized water), one-fifth-strength potato dextrose agar (1/5-PDA; $7.8 \mathrm{~g}$ of PDA (Difco Laboratories), $10 \mathrm{~g}$ of Bacto agar, $150 \mu \mathrm{g}$ of rifampicin [Fisher Scientific Co., Fair Lawn, NJ], and $0.5 \mathrm{~g}$ of ampicillin [Sigma Chemical Co., Steinheim, Germany] per liter of deionized water), or PDA + thiophanate-methyl (Topsin-M 70WP; Cerexagri Inc., King of Prussia, PA; $39 \mathrm{~g}$ of PDA, $0.1 \mathrm{~g}$ of thiophanate-methyl, $150 \mu \mathrm{g}$ of rifampicin, and $0.5 \mathrm{~g}$ of ampicillin per liter of deionized water).

Samples were incubated at $25^{\circ} \mathrm{C}$ and were observed for up to 5 days. Nonsporulating, Rhizoctonia-like colonies with hyphae that had characteristic right- and acute-angled branching were transferred to PDA + rifampicin + ampicillin (31). Additional hyphal tip transfers were made to obtain pure cultures. Isolates were maintained in the dark at $25^{\circ} \mathrm{C}$. For extended storage, isolates were transferred to sterilized oat seed that had been autoclaved for three consecutive days for $30 \mathrm{~min}$ each time. The inoculated oat seed was incubated for 2 to 3 weeks, dried in autoclaved paper bags, and stored at $15^{\circ} \mathrm{C}$.

Colony and fungal characteristics. Size, color, and morphology of sclerotia were noted for five uncharacterized W. circinata (UWC) isolates from diseased SP on four golf courses after the fungi were grown at $25^{\circ} \mathrm{C}$ for 28 days on PDA. To measure hyphal width and the number of nuclei per cell, isolates were transferred to sterilized microscope slides coated with $2 \%$ water agar and incubated at $25^{\circ} \mathrm{C}$ in the dark for 2 days. Mycelia on the agar-coated slides were stained with $6 \mathrm{ml}$ of $0.5 \%$ (wt/vol) safranin-O (Fisher Scientific Co.) in distilled water, $3.0 \%$ (wt/vol) $\mathrm{KOH}$, and $5 \mathrm{ml}$ of glycerol. Diameters of nine hyphal strands per isolate were measured, and nuclei per cell were counted (3).

Internal transcribed spacer region DNA sequencing. Ribosomal DNA (rDNA), including the internal transcribed spacer (ITS)1, the $5.8 \mathrm{~S}$ ribosomal subunit, and ITS2, were sequenced from the five UWC isolates and compared with the sequences of other plant-pathogenic fungi, including Thanatephorus, Waitea, Ceratobasidium, and Sclerotinia spp. Approximately $50 \mathrm{mg}$ of aerial mycelium from each isolate was removed from agar plates and macerated in $20 \mu \mathrm{l}$ of sterile, distilled, deionized water for 1 min with a 0-3200 SPM Mini-Bead beater operated at medium speed (Biospec Products, Bartlesville, OK). A Qiagen Quick Clean-Up DNA extraction kit (Qiagen Inc., Valencia, CA) was used to extract DNA from the macerated samples according to the manufacturer's instructions. Approximately $100 \mathrm{ng}$ of template DNA was used for each $50-\mu$ l polymerase chain reaction (PCR) reaction with $20 \mathrm{pM}$ of each oligonucleotide primer (ITS1 and ITS4) and the RED Extract-N-Amp PCR reaction mix (SigmaAldrich, St. Louis; 39). An Eppendorf AG 22331 thermocycler (Hamburg, Germany) was set for an initial 3-min cycle at $94^{\circ} \mathrm{C}$; followed by 35 cycles of $94^{\circ} \mathrm{C}$ for $1 \mathrm{~min}, 55^{\circ} \mathrm{C}$ for $1 \mathrm{~min}$, and $72^{\circ} \mathrm{C}$ for $1 \mathrm{~min}$; with one final cycle of $72^{\circ} \mathrm{C}$ for $10 \mathrm{~min}$ and a $4^{\circ} \mathrm{C}$ indefinite holding cycle. PCR product $(5 \mu \mathrm{l})$ was electrophoresed in a $1.5 \%$ agarose gel with $0.005 \%$ ethidium bromide. The presence of the expected 650-bp amplicon was visualized with UV light after ethidium bromide staining.

DNA cloning. The PCR product for each isolate of UWC was cleaned with the QuickLyse Miniprep 250 kit (Qiagen Inc.) according to the manufacturer's directions. The PCR products for each isolate were inserted into Escherichia coli and cloned with a Topo TA Kit (Invitrogen, Carlsbad, CA). Five white bacterial clones per isolate were cultured in Luria-Bertani (LB) broth in a shaker incubator at $37^{\circ} \mathrm{C}$ for 14 to $16 \mathrm{~h}$. The transformed bacterial clones were lysed and cleaned with a miniprep kit according to the manufacturer's directions (Qiagen QuickLyse Miniprep kit; Qiagen Inc.).

The purified plasmids were submitted for sequencing to the Interdisciplinary Center for Biotechnology Research at the University of Florida in Gainesville. All sequences were aligned using the Clustal W method in Mega Build 4.02 (Center for Evolutionary Functional Genomics, Tempe, AZ). After removing the primer sequences, consensus sequences were derived using three or more clone sequences for each isolate. A phylogenetic tree was constructed in Mega Build 4.02 using a neighbor-joining algorithm for the Kimura two-parameter model, and a genetic distance matrix was determined (5). Bootstrap values in Mega Build 4.02 were determined based on 1,000 random samples of the data set.

Temperature and growth studies. The five UWC isolates, an isolate of $W$. circinata var. zeae, and an isolate of W. circinata var. circinata were evaluated for colony growth rate at each of six temperatures. A mycelial plug ( $5 \mathrm{~mm}$ in diameter) was removed from the edge of a colony of each isolate on PDA, transferred to a 9-cmdiameter petri plate of PDA, and incubated at 15, 20, 25, 30, 35, or $40^{\circ} \mathrm{C}$ in the dark. Colony diameter was measured every $24 \mathrm{~h}$ for 4 days or until the colony filled the plate. There were three replicate plates for each isolate, and the test was performed twice. Growth rates (millimeters per day) were calculated for the first $24 \mathrm{~h}$ and rates were averaged across the six temperatures. Average growth rate data were analyzed with analysis of variance (ANOVA) in SAS (version 9.0; SAS Institute, Cary, NC). Fisher's least significant difference (LSD) test was used to separate means by isolate $(P$ $=0.05$ ).

Pathogenicity studies. Inoculations with the five UWC isolates were made onto two cultivars of SP (SeaDwarf and SeaIsle Supreme). A qualitative disease incidence assessment was made 3 days after inoculation, and the test was repeated two times. In subsequent inoculation experiments, isolate SK-PSA-TM4 was inoculated onto SeaDwarf and SeaIsle Supreme SP, 'Senesta' seeded

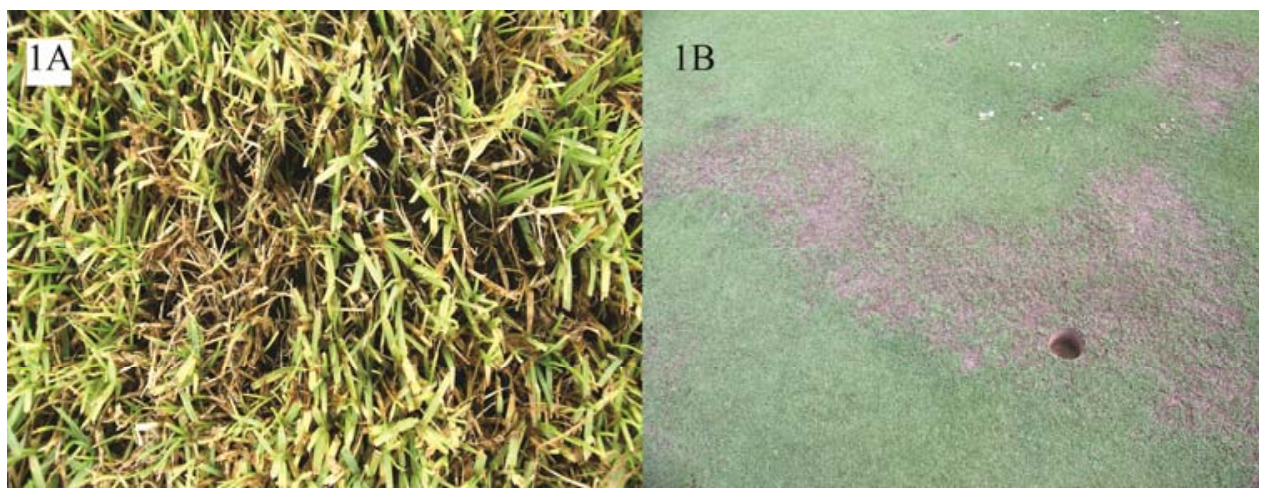

Fig. 1. Symptoms of basal leaf blight of seashore paspalum on A, 'Sealsle Supreme' and B, 'SeaDwarf' in south Florida. 
bermudagrass ( $C$. dactylon), and 'Dark Horse' roughstalk bluegrass (Poa trivialis L.). Disease severity was rated 3 days after inoculation, and the experiment was repeated. In a final inoculation experiment, the five UWC isolates were inoculated onto 'Penncross' creeping bentgrass (Agrostis stolonifera L.). Disease severity was assessed 3 days after inoculation. The experiment was repeated. In all inoculation experiments, three replications per isolate and host combination were used. Data from multiple repetitions of experiments were combined where statistically appropriate and unless otherwise specified.

Cool-season grasses and bermudagrass were seeded into 7.5-cmdiameter pots filled with calcine clay (Turface MVP; Profile Products LLC, Buffalo Grove, IL). The grass was grown for at least 3 weeks with up to one foliar trimming prior to but not the day of inoculation. Granular fertilizer was applied once at $0.3 \mathrm{~g} / \mathrm{pot}$ (6-128 starter fertilizer; Harrell's LLC, Lakeland, FL).

SP was sprigged into either $7.5-$ or $10.0-\mathrm{cm}$-diameter pots by placing five to eight stolon pieces of SP on the surface of each pot filled with calcine clay, and the pots were irrigated. The SP was fertilized twice with 6-12-8 fertilizer at $0.3 \mathrm{~g}$ per 7.5 -cm-diameter pot and $0.5 \mathrm{~g}$ per $10-\mathrm{cm}$-diameter pot 1 month after sprigging. The SP was trimmed weekly for approximately 3 months, until the turfgrass canopy covered each pot. Inoculations were made approximately 4 months after sprigging.

Inoculum was produced on oat seed. Seed $(50 \mathrm{~g})$ was soaked in $50 \mathrm{ml}$ of distilled water for $24 \mathrm{~h}$ in a $250-\mathrm{ml}$ glass flask with a foam plug. The imbibed seed was autoclaved for $30 \mathrm{~min}$ once a day for three sequential days. Sterilized seed was inoculated with five agar plugs transferred from the leading edge of a 1-day-old PDA culture of each isolate. Flasks were maintained in a dark incubator at $25^{\circ} \mathrm{C}$ for 2 to 3 weeks. Approximately every 2 days, the flasks were vigorously shaken to mix the mycelia with the seed. The colonized oat seed was transferred to sterilized paper bags and dried for 2 weeks in a fume hood. Inoculum was stored at $5^{\circ} \mathrm{C}$ in sterilized $100-\mathrm{ml}$ glass vials sealed with Parafilm.

Turfgrass was inoculated by placing five colonized oat seeds equidistant in the foliar canopy of a pot that had been irrigated with $100 \mathrm{ml}$ of water. Each pot was placed in a 30-by-50-cm polyethylene bag containing a moist paper towel to maintain high humidity. The bags were sealed and placed in an incubator for 3 days at $30^{\circ} \mathrm{C}$ with $12 \mathrm{~h}$ of light per day. Pots inoculated with sterile oat seed served as a control treatment for all inoculation experiments.

Disease incidence was assessed 3 days after inoculation of the SP cultivars. Disease severity was assessed on pots of turfgrass utilizing the Horsfall-Barratt rating scale for inoculation experiments with SK-PSA-TM4 and the five UWC isolates on bentgrass (16). Data were subjected to logit transformation and converted to a 0 -to- $100 \%$ severity scale after ANOVA, and means separation was performed according to Fisher's LSD utilizing SAS version 9.0. At the conclusion of these studies, eight pieces of host tissue from at least one replication of each inoculated turfgrass species were excised, surface-sterilized with $70 \%$ ethanol, rinsed, and transferred to $1 / 5$-PDA and water agar. Isolated fungi were trans- ferred into pure culture and identified by morphological characteristics as described above.

\section{Results}

Colony morphology and characterization. A summary of the morphological characteristics of UWC isolates SK-PSA-TM4, SKPMA-WA1, SK-OA-W3-I, SK-OA-TM1, and SK-HBA-W1 is presented in Table 1. All UWC isolates had right- and acute-angle hyphal branching and produced extremely profuse, light-yellow to pink mycelial growth on PDA (Fig. 2A). The aerial mycelium of each isolate clumped, clustered, and attached to the underside of the petri dish lid. No basidiospores or other sexual (teleomorphic) structures were either found associated with the symptomatic turfgrass samples or in vitro at any time up to 120 days after isolation. Irregularly shaped, salmon-colored to brown sclerotia (Fig. 2B), 3 to $>7 \mathrm{~mm}$ in diameter, were observed embedded in the PDA

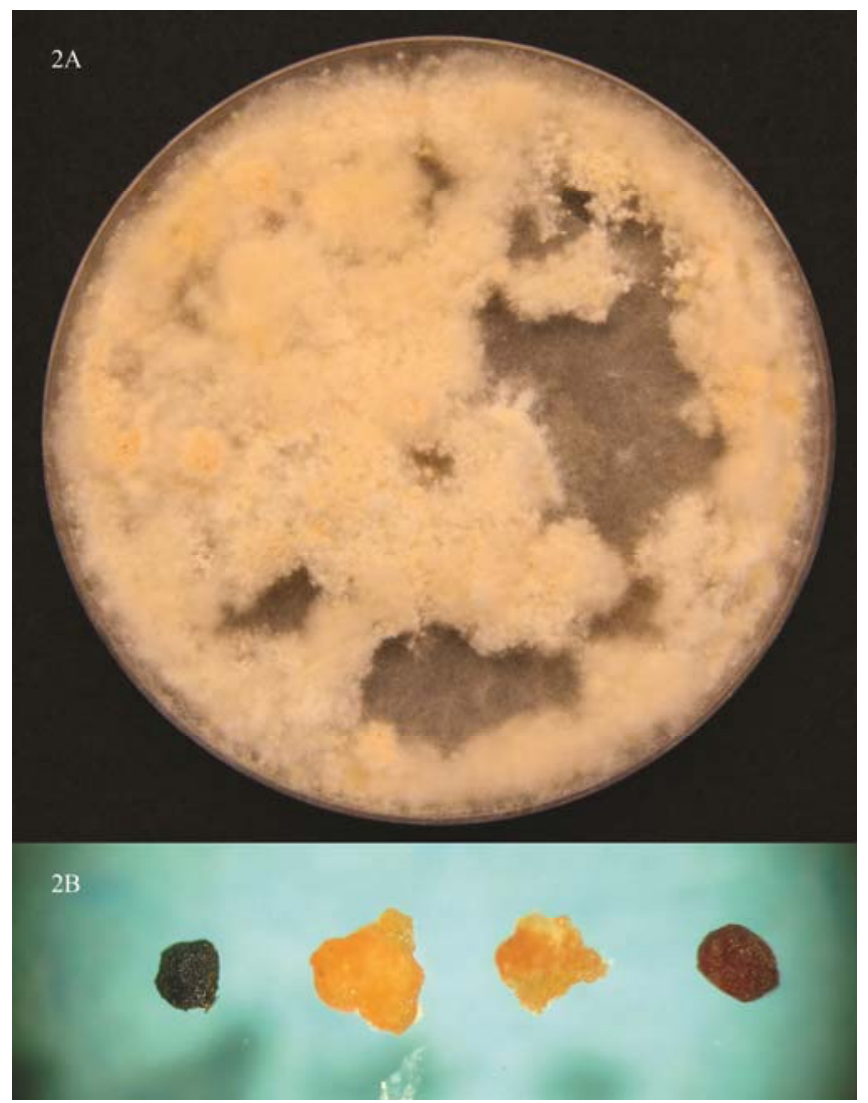

Fig. 2. Characteristics of previously uncharacterized Waitea circinata (UWC) isolates. A, Colony on potato dextrose agar following incubation for 28 days in the dark at $25^{\circ} \mathrm{C} ; \mathrm{B}$, differences in sclerotial characteristics, left to right, of $W$. circinata var. circinata (SK-SMd), UWC (SK-PSA-TM4), W. circinata var. oryzae (SK-3OAW1-I), and W. circinata var. zeae (SK-HBA-W1).

Table 1. Comparison of hyphal and sclerotial characteristics of isolates from symptomatic seashore paspalum in south Florida

\begin{tabular}{|c|c|c|c|c|c|}
\hline \multirow[b]{2}{*}{ Isolate } & \multirow[b]{2}{*}{ Colony morphology $y^{x}$} & \multicolumn{2}{|c|}{ Hyphaew $^{\text {w }}$} & \multicolumn{2}{|l|}{ Sclerotia } \\
\hline & & Diameter $(\mu \mathrm{m})$ & Nuclei & Characteristics $^{y}$ & Size $(\mathbf{m m})^{z}$ \\
\hline SK-PSA-TM4 & Yellow-pink, aerial clumping, monilioid cells & $5 \pm 0.5$ & $7 \pm 1.1$ & Many, clumped, irregular, salmon, in agar & $5 \pm 1.7$ \\
\hline SK-PMA-WA1 & Yellow-pink, aerial tufted growth & $5 \pm 0.4$ & $7 \pm 1.4$ & Many, irregular, yellow-salmon, in agar & $3 \pm 1.0$ \\
\hline SK-OA-W3-I & Yellow-pink, aerial clumping, monilioid cells & $5 \pm 0.6$ & $7 \pm 1.7$ & Sparse to none, yellow, spherical, in agar & $5 \pm 1.0$ \\
\hline SK-OA-TM1 & Yellow, aerial clustered clumping, monilioid cells & $5 \pm 0.3$ & $6 \pm 2.5$ & $\begin{array}{l}\text { Sparse, clumped, irregular, yellow-orange, } \\
\text { in agar }\end{array}$ & $7.4 \pm 2.6$ \\
\hline SK-HBA-W1 & Yellow-pink aerial clumping & $5 \pm 0.4$ & $7 \pm 1.7$ & $\begin{array}{l}\text { Erratic, abundant, salmon-cream, } \\
\text { catenulate, scattered in agar }\end{array}$ & $3.4 \pm 1.6$ \\
\hline
\end{tabular}

\footnotetext{
${ }^{\mathrm{w}}$ Mean and standard deviation $(n=9)$ of hyphae diameter and number of nuclei per cell after 2 days on $2 \%$ water agar.

${ }^{x}$ Maintained on potato dextrose agar (PDA) at $25^{\circ} \mathrm{C}$ in the dark for 28 days.

y In agar means sclerotia were produced at and under the surface of the agar medium.

${ }^{\mathrm{z}}$ Mean $(n=9)$ and standard deviation of diameter of sclerotia after 28 days on potato dextrose agar.
} 
after 2 to 4 weeks of incubation. Isolate SK-3-OA-W3-I produced sclerotia that were light yellow, whereas SK-HBA-W1 produced light-brown sclerotia. Hyphal diameter averaged $5 \mu \mathrm{m}$ with six to seven nuclei per cell for each UWC isolate.

Maximum growth rates for the UWC isolates occurred at $30^{\circ} \mathrm{C}$ (Fig. 3). When comparing rates of growth on PDA encompassing temperatures from 15 to $40^{\circ} \mathrm{C}$, SK-PSA-TM4, SKOA-TM1, and SK-OA-W3-I had statistically similar growth rates that were significantly greater than the growth rates of isolates SK-PMA-W1, SK-HBA-W1, and SK-SMd (Table 2). The growth rate of isolate SK-BA-W1 was significantly greater than that of all the other isolates tested. The growth rate of isolate SK-SMd was significantly less than that of all other isolates tested (Table 2).

rDNA-ITS sequence analysis. Isolates used for the analysis and GenBank accession numbers are given in Table 3. Genetic pairwise distances for all ITS sequences according to the Kimura twoparameter model had a range of 0.000 to 1.697 (data not shown). When pairing sequences, the smaller the number, the greater the similarity between the sequences, and the larger the number, the greater the dissimilarity between the sequences. The minimum and maximum genetic distance among the UWC isolates was 0.000 and 0.0021 (100 and $99.79 \%$ similarity, respectively), with no more than $1 \mathrm{bp}$ difference in the 589 bp sequenced. A 9- to 14-bp

Table 2. Mycelial growth rates of Waitea circinata isolates after $24 \mathrm{~h}$ on potato dextrose agar

\begin{tabular}{|c|c|}
\hline Isolate & Growth rate $(\mathrm{mm} / \mathrm{day})^{\mathrm{z}}$ \\
\hline SK-BA-W1 & $22 \mathrm{a}$ \\
\hline SK-PSA-TM4 & $20 \mathrm{~b}$ \\
\hline SK-OA-TM1 & $20 \mathrm{~b}$ \\
\hline SK-OA-W3-I & $20 \mathrm{~b}$ \\
\hline SK- PMA-W1 & $19 \mathrm{c}$ \\
\hline SK-HBA-W1 & $17 \mathrm{~d}$ \\
\hline SK-SMd & $11 \mathrm{e}$ \\
\hline
\end{tabular}

${ }^{\mathrm{z}}$ Mean $(n=36)$ growth rate. Isolate SK-BA-W1 is $W$. circinata var. zeae and SK-SMd is W. circinata var. circinata. Means followed by the same letter are statistically similar according to Fisher's least significant difference $(\alpha=0.05)$. difference was detected between UWC isolates and W. circinata var. agrostis isolates (30).

The UWC isolates formed a distinct phylogenic clade with $99 \%$ support (Fig. 4). The clade formed by the UWC isolates was closest to the clade formed by $W$. circinata var. agrostis, followed by the W. circinata var. zeae clade and the W. circinata var. circinata single-isolate clade. The W. circinata var. oryzae clade was most distant from the UWC clade (Fig. 4).

Turfgrass pathogenicity studies. Both cultivars of SP developed symptoms following inoculation with each of the UWC isolates. Symptoms included water soaking, chlorosis, and then necrosis of the lower leaf blades and sheaths 3 days after inoculation. Abundant aerial mycelium was observed in the lower leaf canopy for each isolate (Fig. 5). Symptoms developed in

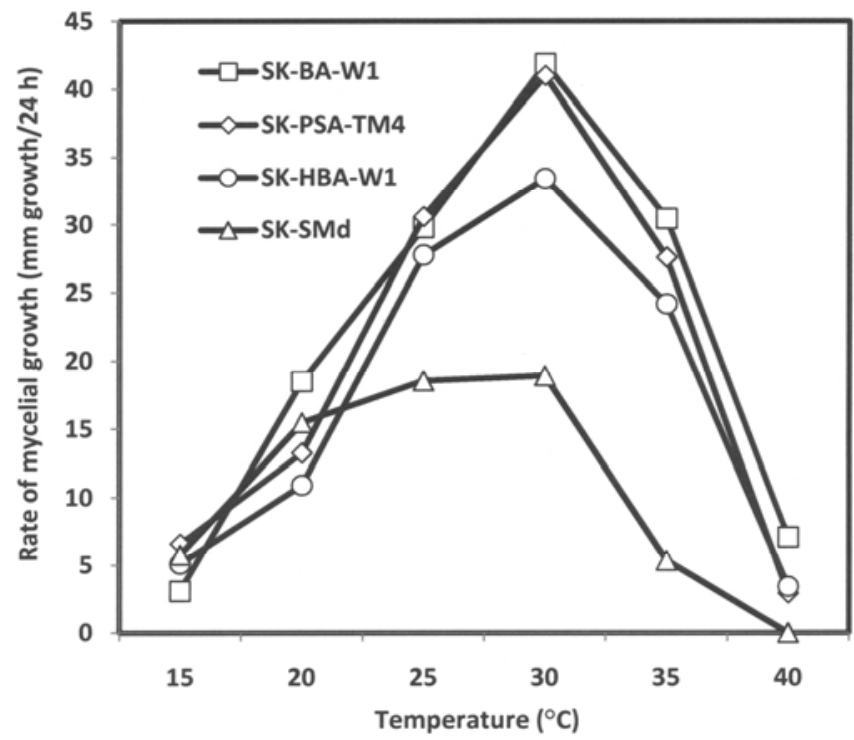

Fig. 3. Comparison of mycelial growth rates (millimeters per day) of Waitea circinata varieties on potato dextrose agar at $15,20,25,30,35$, and $40^{\circ} \mathrm{C}$. SK-BAW1 is variety zeae, SK-PSA-TM4 and SK-HBA-W1 are variety prodigus, and SKSMd is variety circinata.

Table 3. Isolates of Waitea circinata and related fungi that were examined utilizing ribosomal DNA internal transcribed spacer region sequences

\begin{tabular}{|c|c|c|c|c|c|}
\hline Isolate no. & Host $^{x}$ & Origin & Date collected & Identity $^{y}$ & $\begin{array}{c}\text { GenBank } \\
\text { accession no. }\end{array}$ \\
\hline 01 SK-SMd & Annual bluegrass & Reston, VA & 25 April 2008 & Waitea circinata var. circinata & FJ154894 \\
\hline 05 SK-BA1 & 'SeaIsle 2000' SP & Boca Raton, FL & 4 September 2007 & W. circinata var. zeae & HM597140 \\
\hline 09 SK-4OA3-1/5 & 'SeaIsle Supreme' SP & Sarasota, FL & 4 September 2007 & W. circinata var. zeae & HM597139 \\
\hline 14 SK-3OA-TM & 'SeaIsle Supreme' SP & Sarasota, FL & 30 October 2007 & W. circinata var. zeae & HM597141 \\
\hline 36 SK-OA-W3-I & 'SeaIsle Supreme' SP & Sarasota, FL & 9 July 2008 & UWC & HM597147 \\
\hline 39 SK-HBA1 & 'SeaDwarf' SP & Naples, FL & 9 July 2008 & W. circinata var. oryzae & HM597138 \\
\hline 42 SK-0821 BG & 'Tifeagle' bermudagrass & Columbia, SC & 24 August 2008 & W. circinata var. oryzae & HM597137 \\
\hline 44 SK-PSA-TM4 & 'SeaDwarf' SP & Ft. Myers, FL & 4 January 2008 & UWC & HM597146 \\
\hline 45 SK-OA-TM1 & 'SeaIsle Supreme' SP & Sarasota, FL & 4 January 2008 & UWC & HM597144 \\
\hline 46 SK-HBA-W1 & ‘SeaDwarf' SP & Naples, FL & 4 January 2008 & UWC & HM597143 \\
\hline 59 SK-OA-W1-II & 'SeaDwarf' SP & Sarasota, FL & 4 November 2008 & W. circinata var. oryzae & HM597135 \\
\hline 60 SK-4BWB-W1 & 'SeaIsle 2000' SP & Boca Raton, FL & 6 January 2009 & W. circinata var. oryzae & HM597134 \\
\hline 61 SK-PB-TM1 & 'SeaDwarf' SP & Boca Raton, FL & 6 January 2009 & Ceratobasidium $\mathrm{sp}$. & HM597133 \\
\hline 66 SK-PMA-WA1 & 'SeaDwarf' SP & Ft. Myers, FL & 26 August 2008 & UWC & HM597145 \\
\hline $69 \mathrm{SK}-3 \mathrm{OB} 1 \mathrm{~W}$ & 'SeaIsle Supreme' SP & Sarasota, FL & 30 October 2007 & Thanatephorus cucumeris AG2-2IIIB & HM597131 \\
\hline 70 SK-OA-W1-I & 'SeaIsle Supreme' SP & Sarasota, FL & 4 November 2008 & W. circinata var. oryzae & HM597136 \\
\hline 74 SK-820 BG & 'Tifeagle' bermudagrass & West Palm Bch, FL & 10 July 2008 & W. circinata var. zeae & HM597142 \\
\hline 76 3BWA-TM2 & 'SeaIsle 2000' SP & Boca Raton, FL & 6 January 2009 & Thanatephorus cucumeris AG2-2LP & HM597132 \\
\hline 90 ATCC MYA-4521z & Culture collection & Manassas, VA & April 2009 & Sclerotinia sclerotiorum & FJ810516 \\
\hline $91 \mathrm{NUK}-3 \mathrm{BG}^{\mathrm{z}}$ & Creeping bentgrass & Aichi, Japan & June 1999 & W. circinata var. agrostis & AB213567 \\
\hline 92 DAI-BG & Creeping bentgrass & Hyoga, Japan & July 1998 & W. circinata var. agrostis & AB213569 \\
\hline 93 OHT-BG ${ }^{z}$ & Creeping bentgrass & Chiba, Japan & June 1997 & W. circinata var. agrostis & AB2 13578 \\
\hline $94 \mathrm{SHO}-\mathrm{BG}^{\mathrm{z}}$ & Creeping bentgrass & Kanagawai, Japan & July 1999 & W. circinata var. agrostis & AB2 13575 \\
\hline
\end{tabular}

${ }^{\mathrm{x}}$ Annual bluegrass (Poа аппиа L.), SP = seashore paspalum (Paspalum vaginatum Swartz), bermudagrass (Cynodon dactylon (L.) Pers.), creeping bentgrass (Agrostis stolonifera L.).

y $\mathrm{UWC}=$ previously uncharacterized variety of $W$. circinata .

${ }^{\mathrm{z}}$ DNA sequence and other information were obtained from GenBank. 
each of the three repetitions of the experiment, and isolates were recovered from symptomatic tissue for each isolate on each SP cultivar. No symptoms were observed in the noninoculated control treatments.

UWC isolate SK-PSA-TM4 caused an average of 57 to $97 \%$ disease severity on SeaDwarf SP, Senesta bermudagrass, SeaIsle Supreme SP, and Darkhorse roughstalk bluegrass after 3 days of incubation at $30^{\circ} \mathrm{C}$ (Table 4). Disease severity was greatest on roughstalk bluegrass. For all the turfgrass cultivars inoculated, the lower leaves were blighted and the sheaths turned yellow to brown, with a water-soaked appearance. Mycelium was copiously present in the lower and upper turfgrass canopy. The infected turfgrass was uniformly blighted and water-soaked in appearance, with little to no healthy tissue remaining 3 days after inoculation. There were no individual or distinct leaf or sheath lesions present. Isolates used in the pathogenicity studies were recovered from necrotic foliage of the various turfgrass species inoculated.

The UWC isolates SK-PSA-TM4, SK-OA-TM1, SK-HBA-W1, SK-PMA-WA1, and SK-OA-W3-I caused $98 \pm 1.4,92 \pm 7.0,88 \pm$ $7.3,85 \pm 13$, and $78 \pm 15 \%$ disease severity (mean \pm standard deviation), respectively, on creeping bentgrass 3 days after inoculation. Prolific aerial mycelium of each isolate grew throughout the lower turfgrass canopy. Water-soaking and necrosis of the leaf blades and sheaths were visible by day 2 . Disease symptoms with all UWC isolates on all turfgrass species began as a lower (basal) leaf blight, quickly progressing to an overall crown and foliar blight. No leaf spots, lesions, or sclerotia were observed.

\section{Discussion}

The discovery of a "new" SP disease and associated Rhizoctonia-like fungus merits a discussion of the taxonomy of the group. Over the last 150 years, diverse groups of fungal species have been assigned to the form-genus Rhizoctonia s. 1. (1,7,13,21,23,24, 26,27). However, taxonomic reclassifications and clarifications have resulted in the development of several new anamorphic genera, each associated with a distinct teleomorphic genus. For example, the anamorphs of the genera Thanatephorus, Ceratobasidium, and Waitea are currently recognized as Rhizoctonia (33), Ceratorhiza (23), and Chrysorhiza (32), respectively. Taxonomy and nomenclature of the teleomorphs of Rhizoctonia-like fungi have been based on characteristics of basidiocarps, sterigmata, basidiospores, and other sexual structures $(31,32)$. Teleomorphs of the Rhizoctonia-like pathogens of turfgrass rarely are observed; therefore, isolate identification tends to be based on the morphology of anamorphs, which lack asexual spores and fruiting bodies (4). Traditionally, characteristics such as mycelial color, the number of nuclei per hyphal cell, and the shape, size, and color of sclerotia have been used to identify these fungi (34-36). In addition, isolates

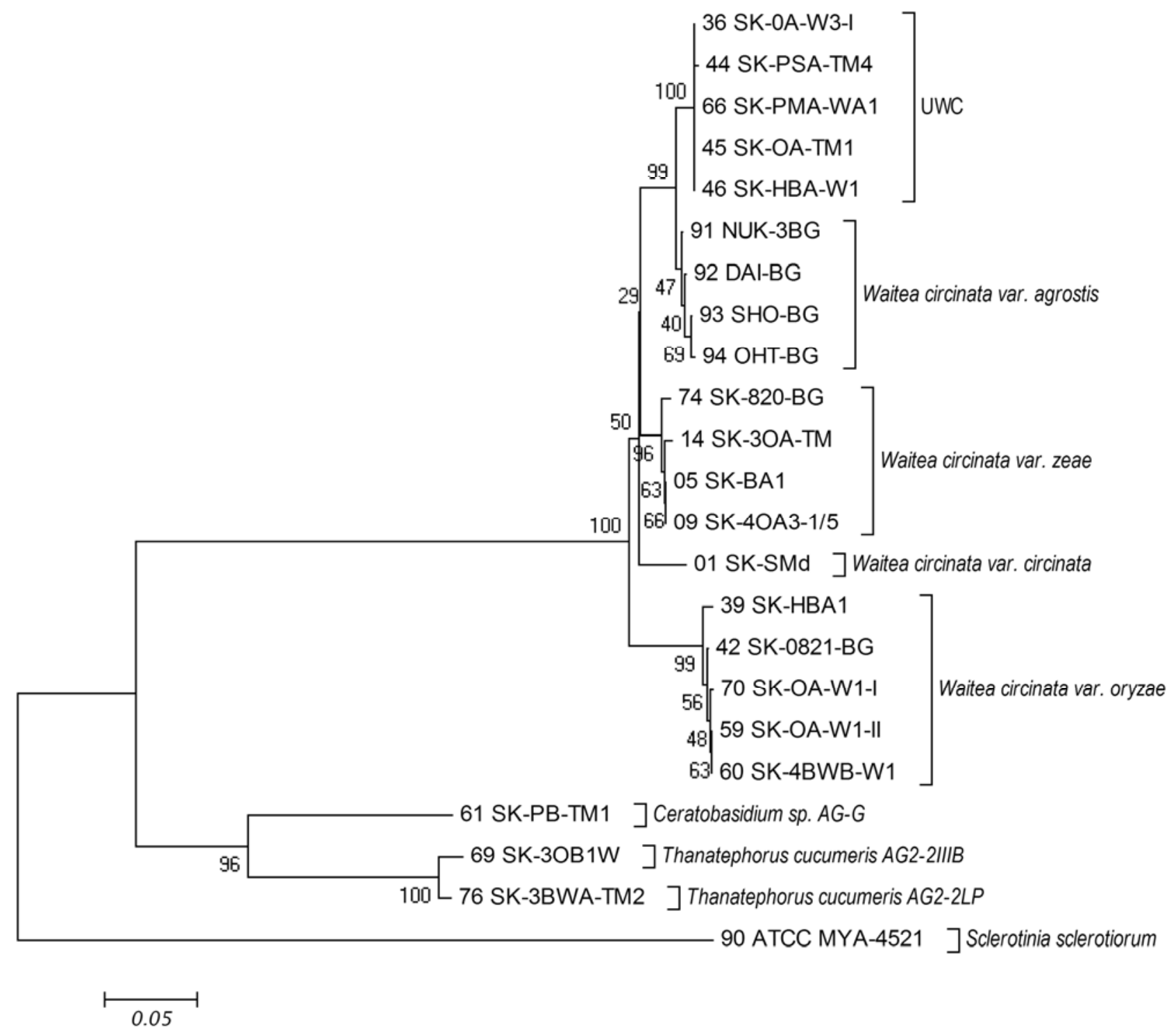

Fig. 4. Phylogenetic distance tree comparing nucleotide sequences from the ribosomal DNA of Waitea circinata isolates and related fungi. Confidence values on the branches were obtained for 1,000 bootstrap replicates with Mega version 4.02 software. 


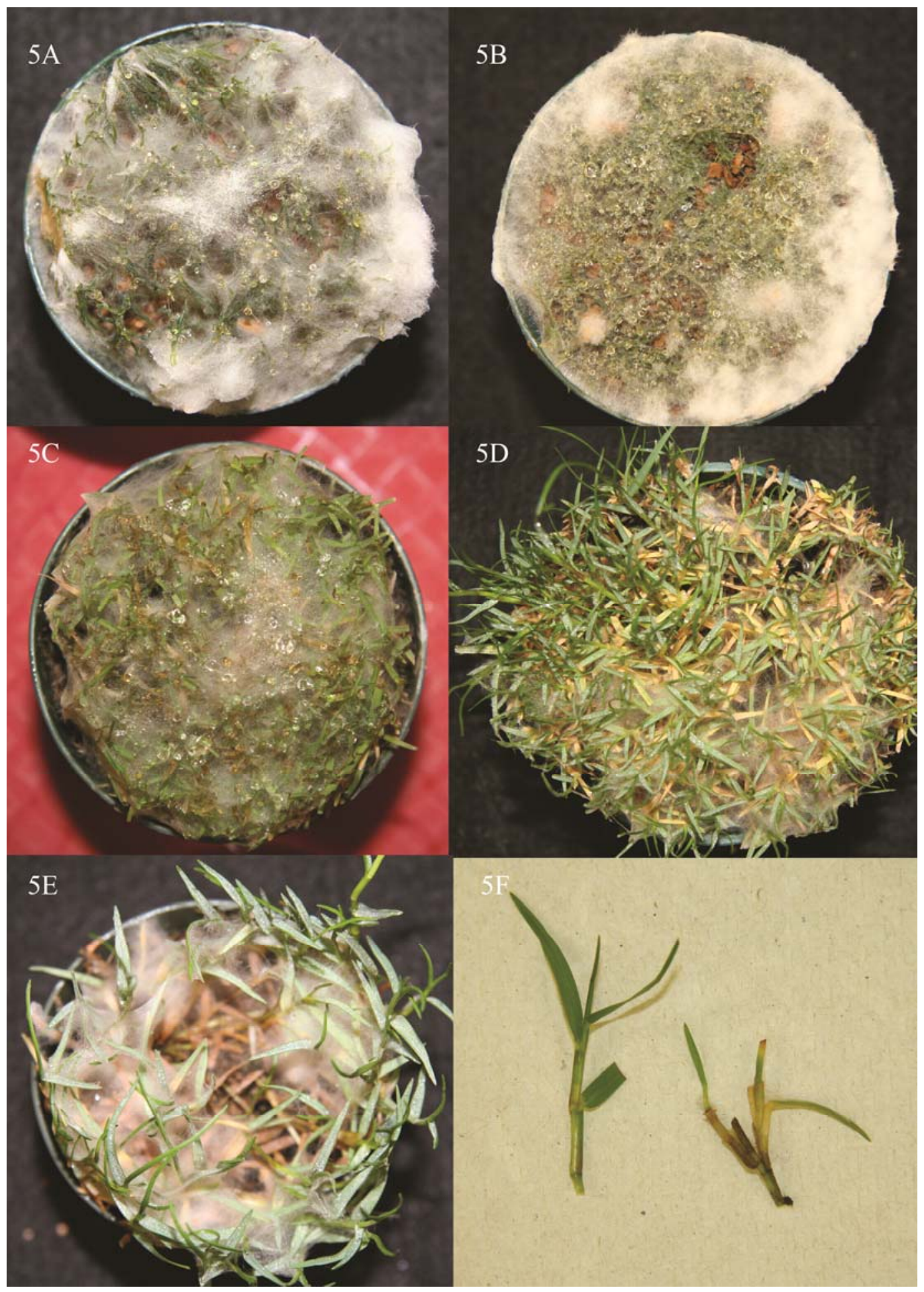

Fig. 5. Symptoms of basal leaf blight caused by Waitea circinata var. prodigus isolate SK-PSA-TM4 3 days after inoculation on A, 'Penncross' creeping bentgrass; B, 'Dark Horse' Poa trivialis; C, 'Senesta' bermudagrass; D, 'SeaDwarf' seashore paspalum; and E, 'Sealsle Supreme' seashore paspalum. F, Shoots of SeaDwarf seashore paspalum noninoculated (left) and inoculated (right) with isolate SK-PSA-TM4.

have been grouped based on the ability of hyphae to anastomose $(6,13,17,27,33,37)$.

The hymenomycete $W$. circinata Warcup \& P.H.B. Talbot (38) was described to include fungi similar to Thanatephorus spp. but having horn-like sterigmata shorter than Thanatephorus spp. and basidiospores that fail to undergo repetitive germination. Mycelia of $W$. circinata were considered to be saprobic (38) prior to the diagnosis of what is believed to be the anamorph, Chrysorhiza zeae (Voorhees) T.F. Andersen \& Stalpers (=R. zeae; 12,26,32), as a pathogen of several members of the genus Poaceae $(4,12)$. Isolates of $C$. zeae also have been referred to as W. circinata var. zeae $(7,34,36)$. The epithet Chrysorhiza was created to accommodate fungi with a Waitea teleomorph (32), while Rhizoctonia anamorphs are associated with Thanatephorus (33).

In addition to $C$. zeae, two additional fungi, $R$. oryzae Ryker \& Gooch (27) and a species with the suggested name $R$. circinata (18), are characterized as anamorphs of $W$. circinata $(18,27,28)$. These Rhizoctonia spp. appear to fit the concept of Chrysorhiza but the original names were not published according to the tenets of the International Code of Botanical Nomenclature (1). Therefore, 
Table 4. Pathogenicity of Waitea circinata isolate SK-PSA-TM4 on seashore paspalum, bermudagrass, and roughstalk bluegrass

\begin{tabular}{|c|c|c|c|c|}
\hline \multirow[b]{2}{*}{ Inoculum } & \multicolumn{4}{|c|}{ Disease severity $(\%)^{x}$} \\
\hline & 'SeaIsle Supreme' SP & 'SeaDwarf' SP & 'Senesta' bermudagrass ${ }^{\mathbf{y}}$ & 'Dark Horse' roughstalk bluegrass ${ }^{\mathrm{z}}$ \\
\hline Noninoculated & $10 \mathrm{~b}$ & $5 \mathrm{~b}$ & $5 \mathrm{~b}$ & $3 \mathrm{~b}$ \\
\hline SK-PSA-TM4 & $69 a$ & $57 \mathrm{a}$ & $57 \mathrm{a}$ & $97 \mathrm{a}$ \\
\hline
\end{tabular}

supplementary taxonomic work (i.e., designation of type, Latin diagnoses) is required before $R$. oryzae and $R$. circinata are recognized as Chrysorhiza spp. In the meantime, reference to W. circinata vars. oryzae and circinata is appropriate.

Sequences from phylogenetically conserved regions of DNA such as the rDNA ITS region have been used to distinguish varieties of $W$. circinata $(7,12,18,29)$. Isolates may be identified based on the similarity of conserved sequences such as ITS1, the $5.8 \mathrm{~S}$ ribosomal subunit, and ITS2 when teleomorphic structures are not present $(7,29)$. The UWC isolates we found associated with SP in Florida appear to be morphologically and genetically distinct from previously described species affecting turfgrass. Morphological characteristics that distinguished the SP isolates from established varieties of $W$. circinata included abundant, yellow to pink aerial mycelium on PDA and salmon to yellow-brown aggregated sclerotia measuring 3.4 to $7.3 \mathrm{~mm}$ in diameter embedded in the agar medium after 2 to 4 weeks of incubation at $30^{\circ} \mathrm{C}$ on full-strength PDA. In addition, analyses of rDNA sequences revealed that the isolates from diseased SP formed a clade that was significantly distinct from that of isolates of $W$. circinata vars. agrostis, circi$n a t a$, oryzae, or zeae. Variability in growth rates, host ranges, temperature optima, disease symptoms, and hyphal and sclerotia color reinforce the differentiation of the UWC clade.

Based on morphological and sequence data, we propose that these isolates from SP comprise a new variety designated $W$. circinata var. prodigus. DNA sequence data indicated that isolates of $W$. circinata var. prodigus were only 97 to $98 \%$ similar to W. circinata var. agrostis and formed a distinct clade with $99 \%$ support in an ITS phylogenetic tree. Isolates of $W$. circinata var. agrostis were recovered from diseased creeping bentgrass in Japan (30). They were not observed to produce abundant, yellow to pink mycelium, and the sclerotia were only 1 to $3 \mathrm{~mm}$ in diameter and dark brown in contrast to the sclerotial described above as characteristic of $W$. circinata var. prodigus.

Diagnostic differentiation among Thanatephorus and Waitea spp. anamorphs affecting SP could be assisted greatly by routinely plating samples on both standard and thiophanate methyl-amended $(100 \mu \mathrm{g} / \mathrm{ml})$ agar media. Growth of the LP strain of $R$. solani that causes large patch is inhibited on the amended medium. Isolates of $C$. zeae that cause leaf and sheath spot, and W. circinata var. prodigus, will grow on both media but the prodigus isolates appear more floccose within $48 \mathrm{~h}$ of plating. Misidentification of these pathogens could result in unnecessary applications of ineffective fungicides. For example, symptoms caused by C. zeae or W. circinata var. prodigus could be confused with brown patch or large patch caused by $R$. solani, resulting in ineffective management of the disease with applications of thiophanate-methyl (10). Accurate identification of the causal agent for fungicide selection is an important factor in turfgrass disease management.

The proposed common disease name of "basal leaf blight", caused by $W$. circinata var. prodigus, is reflective of the aggressive blighting caused by the pathogen on the oldest, basal leaves, progressing over time to form diffuse necrotic patches in turfgrass swards. The rapid colonization and blight of four turfgrass species at $30^{\circ} \mathrm{C}$ in controlled environmental conditions in this study and the rapid growth rate of W. circinata var. prodigus in vitro at 25 to $35^{\circ} \mathrm{C}$ suggest that this pathogen could be a potential threat to multiple species of turfgrass over a wide range of climatic conditions.

\section{Literature Cited}

1. Andersen, T. F., and Stalpers, J. A. 1994. A check-list of Rhizoctonia epithets. Mycotaxon 51:437-457.

2. Ayogai, T., Kageyama, K., and Hyakumachi, M. 1999. Isolation of Pythium species from zoysia grass and their effect on severity of large patch disease. Plant Dis. 83:171-175.

3. Bandoni, R. J. 1979. Safranin O as a rapid nuclear stain for fungi. Mycologia 71:873-874.

4. Burpee, L. L., and Martin, S. B. 1992. Biology of Rhizoctonia species associated with turfgrasses. Plant Dis. 76:112-117.

5. Burpee, L. L., Mims, C. W., Tredway, L. P., Bae, J., and Jung, G. 2003. Pathogenicity of a novel biotype of Limonomyces roseipellis in tall fescue. Plant Dis. 87:1031-1036.

6. Carling, D. E., Kuninaga, S., and Brainard, K. A. 2002. Hyphal anastomosis reactions, rDNA-internal transcribed spacer sequences, and virulence levels among subsets of Rhizoctonia solani anastomosis group 2 (AG-2) and AGBI. Phytopathology 92:43-50.

7. de la Cerda, K., Douhan, G., and Wong, F. 2007. Discovery and characterization of Waitea circinata var. circinata affecting annual bluegrass from the Western United States. Plant Dis. 91:791-797.

8. Duncan, R. R. 2003. Seashore paspalum (Paspalum vaginatum Swartz). Pages 295-307 in: Turfgrass Biology, Genetics, and Breeding. M. D. Casler and R. R. Duncan, eds. John Wiley and Sons, New York.

9. Duncan, R. R., and Carrow, R. N. 2000. Seashore Paspalum, The Environmental Turfgrass. Ann Arbor Press, Chelseas, MI.

10. Elliott, M. L. 1999. Comparison of Rhizoctonia zeae isolates from Florida and Ohio turfgrasses. HortScience 34:298-300.

11. Elmore, W. C., Gooch, M. D., and Stiles, C. M. 2002. First report of Gaeumannomyces graminis var. graminis on seashore paspalum in the United States. Plant Dis. 86:1405.

12. Garcia, M. G., Ramos, E. R., and Ochoa, R. R. 2008. First report of Chrysorhiza zeae (Voorhees) Andersen and Stalpers causing necrotic lesions on Cynodon dactylon (1.) pers. in Cuba. Fitosanidad 12:143-146.

13. Garcia, V. G., Portal Onco, M. A., and Rubio Susan, V. 2006. Review. Biology and systematics of the form genus Rhizoctonia. Span. J. Agric. Res. 4:55-79.

14. Haygood, R. A., and Martin, S. B. 1990. Characterization and pathogenicity of species of Rhizoctonia associated with centipedegrass and St. Augustinegrass in South Carolina. Plant Dis. 74:510-514.

15. Hixson, A. C., Crow, W. T., McSorley, R., and Trenholm, L. E. 2004. Host status of 'SeaIsle 1' seashore paspalum to Belonolaimus longicaudatus and Hoplolaimus galeatus. J. Nematol. 36:493-498.

16. Horsfall, J. G., and Barratt, R. W. 1945. An improved grading system for measuring plant disease. (Abstr.) Phytopathology 35:655.

17. Kuninaga, S., Natsuaki, T., Takeuchi, T., and Yokosawa, R. 1997. Sequence variation of the rDNA ITS regions within and between anastomosis groups in Rhizoctonia solani. Curr. Genet. 32:237-243.

18. Leiner, R. H., and Carling D. E. 1994. Characterization of Waitea circinata (Rhizoctonia) isolated from agricultural soils in Alaska. Plant Dis. 78:385388.

19. Lv, C., Luo, L., and Hsiang, T. 2010. First report of dollar spot of seashore paspalum (Paspalum vaginatum) caused by Sclerotinia homoeocarpa in South China. Plant Dis. 94:373-373.

20. Martin, S. B. 2000. Distinguishing Rhizoctonia diseases on warm season grasses. (Abstr.) Phytopathology 90:S97.

21. Mazzola, M., Wong, O., and Cook R. 1996. Virulence of Rhizoctonia oryzae and $R$. solani AG-8 on wheat and detection of $R$. oryzae in plant tissue by PCR. Phytopathology 86:354-360.

22. McCarty, L. B. 2005. Best turfgrasses for golf courses. Pages 15, 34-37 in: Best Golf Course Management Practices-Second Edition. Pearson Prentice Hall, Upper Saddle River, NJ.

23. Moore, R. T. 1987. The genera of Rhizoctonia-like fungi: Ascorhizoctonia, Ceratorhiza gen. nov., Moniliopsis, and Rhizoctonia. Mycotaxon 29:91-99.

24. Moore, R. T. 1996. The dolipore/parenthesome septum in modern taxonomy. Pages 13-35 in: Rhizoctonia Species: Taxonomy, Molecular Biology, Ecology, Pathology and Disease Control. B. Sneh, S. Jabaji-Hare, S. Neate, and G. Dijst, eds. Kluwer Academic, Dordrecht, The Netherlands.

25. Morton J. F. 1973. Salt tolerant siltgrass (Paspalum vaginatum) Proc. Fla. State Hortic. Soc. 86:482-490. 
26. Oniki, M., Ogoshi, A., Araki, T., Sakai, R., and Tanaka, S. 1985. The perfect state of Rhizoctonia oryzae and R. zeae and the anastomosis groups Waitea circinata. Trans. Mycol. Soc. Jpn. 26:189-198.

27. Priyatmojo, A., Yamauchi, R., Carling, D. E., Kageyama, K., and Hyakumachi, M. 2002. Differentiation of three varieties of Rhizoctonia circinata; var. circinata, var. oryzae and var. zeae on the basis of cellular fatty acid compositions. Phytopathology 150:1-5.

28. Priyatmojo, A., Yamauchi, R., Kageyama, K., and Hyakumachi, M. 2002. Whole-cell fatty acid composition to characterize and differentiate isolates of Rhizoctonia species associated with turfgrass species in Japan. J. Gen. Plant Pathol. 68:1-7.

29. Sharon, M., Kuninaga, S., Hyakumachi, M., Naito, S., and Sneh, B. 2008. Classification of Rhizoctonia spp. using rDNA-ITS sequence analysis supports the genetic basis of the classical anastomosis grouping. Mycoscience 49:93-114.

30. Sharon, M., Kuninaga, S., Hyakumachi, M., and Sneh, B. 2006. The advancing identification and classification of Rhizoctonia spp. using molecular and biotechnological methods compared with the classical anastomosis grouping. Mycoscience 47:299-316.

31. Sneh, B., Burpee, L., and Ogoshi, A. 1991. Pages 1-135. Identification of Rhizoctonia species. American Phytopathological Society, St. Paul, MN.

32. Stalpers, J. A., and Andersen, T. F. 1996. A synopsis of the taxonomy of teleomorphs connected with Rhizoctonia S. L. Pages 49-63 in: Rhizoctonia Species: Taxonomy, Molecular Biology, Ecology, Pathology and Disease Control. B. Sneh, S. Jabaji-Hare, S. Neate, and G. Dijst, eds. Kluwer Aca- demic, Dordrecht, The Netherlands.

33. Stalpers, J. A., Andersen, T. F., and Gams, W. 1998. Two proposals to conserve the names Rhizoctonia and $R$. solani (Hyphomycetes). Taxon 47:725726.

34. Toda, T., Hyakawa, T., Mwafaida Mghalu, J., Yaguchi, S., and Hyakumachi, M. 2007. A new Rhizoctonia sp. closely related to Waitea circinata causes a new disease of creeping bentgrass. J. Gen. Plant Pathol. 73:379-387.

35. Toda, T., Hyakumachi, M., Suga, H., Kageyama, K., Tanaka, A., and Tani, T. 1999. Differentiation of Rhizoctonia AG-D isolates from turfgrass into subgroups I and II based on rDNA and RAPD analyses. Eur. J. Plant Pathol. 105:835-846.

36. Toda, T., Mushika, T., Hayakawa, T., Tanaka, A., Tani, T., and Hyakumachi, M. 2005. Brown ring patch: a new disease on bentgrass caused by Waited circinata var. circinata. Plant Dis. 89:536-542.

37. Yokoyama, K., Hyakumachi, M., and Ogoshi, A. 1985. Studies of hyphal anastomosis of Rhizoctonia-solani. III. Hyphal anastomosis in non-self-anastomosis isolates. Hokkaido Univ. Collect. Scholarly Acad. Pap. 14:416-421.

38. Warcup, J. H., and Talbot, P. H. B. 1962. Ecology and identity of mycelia isolated from soil. Trans. Br. Mycol. Soc. 45:495-518.

39. White, T. Bruns, T., Lee, S., and Taylor, J. 1990. Amplification and direct sequencing of fungal ribosomal RNA genes for phylogenetics. Pages 315 322 in: PCR Protocols: A Guide to Methods and Applications. M. A. Innis, D. H. Gelfand, J. J. Sninsky, and T. J. White, eds. Academic Press, San Diego, CA. 